\title{
Karyotype variability in neotropical catfishes of the family Pimelodidae (Teleostei: Siluriformes)
}

\author{
Américo Moraes $\mathrm{Neto}^{1}$, Maelin da Silva ${ }^{1}$, Daniele Aparecida Matoso ${ }^{2}$, Marcelo Ricardo \\ Vicari $^{1}$, Mara Cristina de Almeida ${ }^{1}$, Maria João Collares-Pereira ${ }^{3}$, \\ and Roberto Ferreira Artoni ${ }^{1}$
}

\begin{abstract}
Karyotypic data are presented for four species of fish belonging to the Pimelodidae family. These species show a conserved diploid number, $2 \mathrm{n}=56$ chromosomes, with different karyotypic formulae. The analyzed species showed little amount of heterochromatin located preferentially in the centromeric and telomeric regions of some chromosomes. The nucleolus organizer regions activity (Ag-NORs) and the chromosomal location of ribosomal genes by fluorescent in situ hybridization (FISH), with $18 \mathrm{~S}$ and $5 \mathrm{~S}$ probes, showing only one chromosome pair marked bearer of ribosomal genes, the only exception was Pimelodus britskii that presented multiple NORs and syntenic location of the $18 \mathrm{~S}$ and $5 \mathrm{~S}$ probes. Non-Robertsonian events, as pericentric inversion and NORs duplication are requested to explain the karyotype diversification in Pseudoplatystoma from the rio Paraguay (MS), Pimelodus from the rio Iguaçu (PR), Sorubim from the rio Paraguay (MS) and Steindachneridion from the rio Paraíba do Sul (SP). The obtained data for the karyotype macrostructure of these species corroborates a conserved pattern observed in Pimelodidae. On the other hand, interspecific variations detected by molecular cytogenetics markers made possible cytotaxonomic inferences and differentiation of the species here analyzed.
\end{abstract}

Dados cariotípicos são apresentados para quatro espécies da família Pimelodidae. Todas apresentaram o mesmo número diploide, $2 \mathrm{n}=56$ cromossomos, com diferenças nas fórmulas cariotípicas. As espécies aqui analisadas mostraram pouca quantidade de heterocromatina localizada preferencialmente na região centromérica e telomérica de alguns cromossosmos do complemento cariotípico. As regiões organizadoras de nucléolo (Ag-RONs) e a localização dos genes ribossomais pela hibridização in situ fluorescente (FISH), com sondas $18 \mathrm{~S}$ e $5 \mathrm{~S}$, evidenciaram somente um par cromossômico marcado portador de genes ribossomais, à exceção de Pimelodus britskii que apresentou NORs múltiplas e localização sintênica das sondas $18 \mathrm{~S}$ e 5S. Eventos não-Robertsonianos, como inversão pericêntrica e duplicação das NORs são requeridos para explicar a diversificação cariotípica em Pseudoplatystoma do rio Paraguai (MS), Pimelodus do rio Iguaçu (PR), Sorubim do rio Paraguai (MS) e Steindachneridion do rio Paraíba do Sul (SP). Os dados obtidos para a macroestrutura cariotípica destas espécies corrobora um padrão conservado observado na família Pimelodidae. Por outro lado, evidências de variações interespecíficas pelos marcadores de citogenética molecular empregados possibilitam inferências citotaxonômicas e diferenciação das espécies aqui analisadas.

Key words: Pseudoplatystoma reticulatum, Pimelodus britskii, Sorubim lima, Steindachneridion parahybae.

\section{Introduction}

According to Lundberg \& Littmann (2003), Pimelodidae is considered one of the most diversified families among Neotropical Siluriformes. Actually clustering 29 genera, 93 species and four nominal fossil species (Ferraris, 2007). Although well known, some species are threatened (Hilsdorf \& Petrere Jr., 2002; Ludwig et al., 2005; Caneppele et al., 2009). Among the great catfishes, the Steindachneridion and Pseudoplatystoma genera occupy the top of the alimentary chain; present great load and migrate in at least a phase of the life (Miranda, 1997; Revaldaves et al., 2005). The genus Pimelodus has the greatest diversity in the Pimelodidae family, with 26 species distributed from Panama to Argentina, ranging from small to medium-size (Lundberg \& Littmann, 2003; Ribeiro \& Lucena, 2006a, 2006b). The genus Sorubim is distributed in hydrographic basins of the Amazon, Orinoco, Paraná and Paraíba Rivers (Froese \& Pauly, 2002).

Cytogenetic studies on species from the Pimelodidae show diploid numbers ranging from $2 n=50$ to $2 n=58$, with most

\footnotetext{
${ }^{1}$ Universidade Estadual de Ponta Grossa, Departamento de Biologia Estrutural, Molecular e Genética. Av. Carlos Cavalcanti, 4748, 84030-900 Ponta Grossa, PR, Brazil. rfartoni@pq.cnpq.br (corresponding author)

${ }^{2}$ Instituto Nacional de Pesquisas da Amazônia. Av. André Araújo, 2936, 69083-000 Manaus, AM, Brazil.

${ }^{3}$ Faculdade de Ciências da Universidade de Lisboa. Departamento de Biologia Animal, 1749-016 Lisboa, Portugal.
} 
species exhibiting $2 \mathrm{n}=56$ chromosomes (Swarça et al., 2007), especially those from the subfamily Sorubiminae. Moreover, the karyotypes are basically composed of metacentric and submetacentric chromosomes, little heterochromatin content and one chromosome pair bearing the nucleolus organizing region (Fenocchio \& Bertollo, 1992; Martins-Santos et al., 1996; Swarça et al., 2001). However, cytogenetic information on this family remains scarce and few species have been analyzed using more in-depth cytogenetic methods, such as staining with base-specific fluorochromes and fluorescent in situ hybridization (for a review see, Oliveira et al., 2005).

In order to enhance the cytogenetic data from pimelodides, especially species used for breeding, four species from different genera were analyzed with the aim of contributing toward the cytotaxonomy and karyotypic comparision of this family of Neotropical fishes.

\section{Material and Methods}

The present study analyzed 29 specimens of Pseudoplatystoma reticulatum raised in captivity at the Fish Farm Station of the MAR \& TERRA Indústria e Comércio de Pescados Ltda. from parentals originating from the rio Paraguay (19 males and 10 females), 14 specimens of Pimelodus britskii from the Hydrobiology Station of the Ney Braga Hydroelectric Plant (Companhia Paranaense de Energia Elétrica - COPEL) came from in the medium rio Iguaçu (5 males and 9 females), 6 specimens of Sorubim lima from the BRFISH Farm from parentals originating from the rio Paraguay (1 male and 5 females) and 10 specimens of Steindachneridion parahybae raised in captivity Hydrobiology and Aquaculture Station of the Paraibuna Hydroelectric Plant (Companhia Energética de São Paulo - CESP) from parentals originating from the rio Paraíba do Sul (6 males and 4 females). The species were taxonomically identified by Oscar A. Shibatta and voucher specimens of each species was deposited at the Museu de Zoologia da Universidade Estadual de Londrina (Londrina, PR, Brazil) under catalog numbers MZUEL 5228
(Pseudoplatystoma reticulatum), MZUEL 5230 (Pimelodus britskii), MZUEL 5231 (Steindachneridion parahybae), and MZUEL 5232 (Sorubim lima).

The obtainment of mitotic chromosomes was performed using the air drying method described by Bertollo et al. (1978). Heterochromatic regions were detected using the Sumner's method (1972) and staining with fluorescent DAPI (4,6 diamino 2-fenil-indol) dye. Nucleolus organizing regions were detected using silver ion impregnation according to Howell \& Black (1980). Fluorescent in situ hybridization for the simultaneous location of $18 \mathrm{~S}$ and $5 \mathrm{~S}$ rDNA (double-FISH) was performed based on the Pinkel et al. (1986) protocols, using the 18S rDNA probes described for Prochilodus argenteus (Hatanaka $\&$ Galetti, 2004) and 5S rDNA probes described for Leporinus obtusidens (Martins \& Galetti, 1999).

Chromosome identification was based on the arm ratio criteria proposed by Levan et al. (1964) and chromosomes were classified as metacentric (m), submetacentric (sm), subtelocentric (st) and acrocentric (a). Fundamental number (FN) was established as the total number of chromosome arms of the diploid complement, considering the " $\mathrm{m}, \mathrm{sm}$ and st" types as having two arms and the "a" type as having a single chromosome arm. Chromosomes were analyzed under an epifluorescence microscope (Olympus BX $41^{\circledR}$ ) and the images were captured using a real time $\mathrm{CCD}\left(\right.$ Olympus DP7 $\left.{ }^{\circledR}\right)$ with a resolution of 12 mega pixels.

\section{Results}

All species analyzed had a diploid number equal to 56 chromosomes, with no morphological evidence of differentiated sex chromosomes or supernumerary chromosomes. The fundamental numbers (FN) and karyotypes formulae were different among the species. These macrostructure data are summarized in Table 1. The heterochromatin were preferentially located in the pericentromeric regions at the 2, 3, 5, 12, 23, 26, 27, 28 and 29 chromosome pairs in P. reticulatum. The chromosomes pairs

Table 1. Karyotype characteristics of the species studied. FN = fundamental number (number of chromosome arms); Ag-NORs $=$ tagging of nucleolar organizing regions by silver colloidal; $18 \mathrm{~S}$ sites $=$ localization of $18 \mathrm{~S}$ rDNA probe; $5 \mathrm{~S}$ sites $=$ localization of $5 \mathrm{~S}$ rDNA probe; $\mathrm{C}$-band $=$ chromosomal localization of heterochromatin; $\mathrm{m}=$ metacentric chromosome; $\mathrm{sm}=$ submetacentric chromosome; $\mathrm{st}=$ subtelocentric chromosome; $\mathrm{a}=$ acrocentric chromosome $p=$ short arm; $q=$ long arm; Cent. Chrom. $=$ centromere of chromosomes; Tel. Chrom. $=$ telomere of chromosomes.

\begin{tabular}{|c|c|c|c|c|c|c|}
\hline Species & Karyotype Formulae & $\mathrm{FN}$ & Ag-NORs & Sites 18S & Sites 5S & C-band \\
\hline Pimelodus britskii & $24 m+18 s m+8 s t+6 a$ & 106 & $\begin{array}{l}q \text { terminal st } \\
\text { chromosome }\end{array}$ & $\begin{array}{l}q \text { terminal st } \\
\text { chromosome } \\
\text { syntenic to } 5 \mathrm{~S}\end{array}$ & $\begin{array}{l}p \text { interstitial sm } \\
\text { chromosome; } \\
q \text { terminal st chromosome } \\
\text { syntenic to } 18 \mathrm{~S}\end{array}$ & $\begin{array}{l}\text { Cent. Chrom. 2, 4, } 26 \text { and } 27 . \\
\text { Tel. Chrom. 2, } 16 \text { and } 18 q \text {; } \\
22 p \text { and } q \text {. }\end{array}$ \\
\hline $\begin{array}{l}\text { Pseudoplatystoma } \\
\text { reticulatum }\end{array}$ & $22 \mathrm{~m}+20 \mathrm{sm}+6 \mathrm{st}+8 \mathrm{a}$ & 104 & $\begin{array}{l}p \text { terminal sm } \\
\text { chromosome }\end{array}$ & $\begin{array}{l}p \text { terminal sm } \\
\text { chromosome }\end{array}$ & $\begin{array}{l}p \text { interstitial sm } \\
\text { chromosome }\end{array}$ & $\begin{array}{l}\text { Cent. Chrom. 2, 3, 5, 12, 23, 26, 27, } \\
28 \text { and } 29 . \\
\text { Tel. Chrom. } 5 \text { and } 19 p \text {; } \\
24 \text { and } 25 q ; 7 \text { and } 8 p \text { and } q .\end{array}$ \\
\hline Sorubim lima & $24 m+16 s m+8 s t+8 a$ & 104 & $\begin{array}{l}p \text { terminal st } \\
\text { chromosome }\end{array}$ & $\begin{array}{l}p \text { terminal st } \\
\text { chromosome }\end{array}$ & $\begin{array}{l}p \text { interstitial sm } \\
\text { chromosome }\end{array}$ & $\begin{array}{l}\text { Cent. Chrom. } 25 \text { and } 28 . \\
\text { Tel. Chrom. 2, } 3 \text { and } 13 q \text { and } q \text {. }\end{array}$ \\
\hline $\begin{array}{l}\text { Steindachneridion } \\
\text { parahybae }\end{array}$ & $4 m+22 s m+12 s t+8 a$ & 104 & $\begin{array}{l}p \text { terminal sm } \\
\text { chromosome }\end{array}$ & $\begin{array}{l}p \text { terminal sm } \\
\text { chromosome }\end{array}$ & $\begin{array}{l}p \text { interstitial sm } \\
\text { chromosome }\end{array}$ & $\begin{array}{l}\text { Cent. Chrom. 9, 19, } 26 \text { and } 27 . \\
\text { Tel. Chrom. 6, 21, 22, } 23 \text { and } \\
24 p \text { and } 4,13 \text { and } 20 p \text { and } q .\end{array}$ \\
\hline
\end{tabular}


5,7 and 19 had heterochromatic regions located in the terminal position in the short arms, while the pair 24, 25 and 28 show marks in the long arms and the pairs 7 and 8 showed heterochromatin at the terminal regions in both arms (bitelomeric marks) (Fig. 1B). The heterochromatin in P. britskii was located in the pericentromeric regions of the chromosomes pairs 2, 4, 26 and 27. The chromosomes pairs 2 and 18 showed slight heterochromatin in the terminal position of the long arms while the pair 22 showed a bitelomeric marks (Fig. 2B). In S. lima, the chromosomes pairs 25 and 28 showed heterochromatin in the pericentromeric regions, while the pairs 2, 3 and 13 had bitelomeric marks (Fig. 3B). Pericentromeric heterochromatin was found in $S$. parahybae at the chromosomes pairs 9, 19,26 and 27. The telomeric bands were observed on the short arm of pairs 6, 21, 22, 23 and 24, while the bitelomeric marks were found in the pairs 4,13 and 20 (Fig. 4B). The silver impregnation showed only one pair of the nucleolus organizer regions (Ag-NORs) located in the terminal portion of the short arm of a submetacentric chromosomic pair in P. reticulatum (Fig. 1D). In P. britskii, the Ag-NORs was located at the terminal portion of the long arm of one subtelocentric chromosome pair (Fig. 2D), while $S$. lima showed also silver impregnation marks in a subtelocentric pair, but in the short arm (Fig. 3D). Steindachneridion parahybae showed the silver impregnation on the short arm of a submetacentric chromosome pair also in terminal position (Fig. 4D). In all species, the Ag-NORs coincided with the $18 \mathrm{~S}$ probe localized by FISH and only a chromosome pair was verified with the $5 \mathrm{~S}$ probe location. These chromosome pairs are comparable between the analyzed species (Figs. 1C, 3C, and 4C), except for $P$. britskii who showed multiples chromosomes with $5 \mathrm{~S}$ sequences located. The double-FISH analysis technique showed syntenic sites for the $18 \mathrm{~S}$ and $5 \mathrm{~S}$ probes localized in the terminal portion of the long arm at the acrocentric chromosome pair in P. britskii, besides two chromosomes with pericentromeric marks and other chromosome with less evident heterochromatin marks about the terminal portion of the long arm (Fig. 2C).

\section{Discussion}

The condition of vulnerable species or those threatened with extinction determined that the present study would be conducted with specimens raised in captivity for all the analyzed species in order to minimize possible impacts on natural populations so as to allow a broader view of the karyotype evolution and conservation of these species (Artoni et al., 2009). The diploid number of 56 chromosomes in here analyzed species supports the hypothesis that this is the modal number verified in most catfish families (Oliveira \& Gosztonyi, 2000) and likely a basal condition found among species of the Pimelodidae. On the other hand the different karyotype formulae verified for Pseudoplatystoma species (revised in Swarça et al., 2007) support the condition of nonconservative karyotype evolution in this genus.
A survey of the species belonging to this Neotropical fish family demonstrated that about $30 \%$ of the 93 nominal species cited by Ferraris (2007) have their karyotype constitution at least preliminarily described (for a review see Oliveira et al., 2005 and access http://www.ibb.unesp.br/ laboratorios/Freshwater\%20Neotropical\%20fishes.pdf). With one third of the species karyotyped, evolutionary trends can be identified, especially for the Pimelodus genus and other supposedly related large catfish in their systematic condition, such as the Pseudoplatystoma, Sorubim, and Steindachneridion genera, although these constitute a polytomy within the Pimelodidae family, according to de Pinna (1998). Undeniably, all species and analyzed populations has demonstrated, thus far, a strong conservative tendency toward the karyotype macrostructure of these species. The same was observed in the present study and we found that Pimelodus britskii exhibited a differentiated character from the other analyzed species regarding the $18 \mathrm{~S}$ and $5 \mathrm{~S}$ rDNA sites location. A quite singular condition indicated syntenic co-location of the $18 \mathrm{~S}$ and $5 \mathrm{~S}$ regions determined by the double-FISH method for one chromosome pair in P. britskii. Thus far, this is an unusual condition among the analyzed fish species especially using this molecular cytogenetic method (Martins \& Galetti Jr., 1999, 2000, 2001). Mechanisms such as conversion and unequal crossing-over often occur within these gene arrangements during evolution, according to Dover (1986). In this context, according to Diniz et al. (2009), the location of $5 \mathrm{~S}$ and $18 \mathrm{~S}$ rDNA sites on different chromosomes and different positions would be a way to restrict the setting of unfavorable rearrangements, for example, translocation of segments between these genes. Under the phylogenetics systematics light, this characterization may place the status of this character as an apomorphy, which is yet to be proven regarding other species from the genus, for example, Pimelodus fur has not exhibited this synteny (Garcia et al., 2005). Moreover, the character robustness must also be tested in relation to the same species in other populations.

On the other hand, the characteristics of the karyotype macrostructure can be considered cytotaxonomic markers for the species studied here. The $22 \mathrm{~m}+20 \mathrm{sm}+6 \mathrm{st}+8 \mathrm{a}$ karyotype formulae found in Pseudoplatystoma reticulatum from the rio Paraguay (rio da Prata basin) is distinct from that described by Fenocchio \& Bertollo (1992), cited as Pseudoplatystoma fasciatum, with $18 \mathrm{~m}+14 \mathrm{sm}+10 \mathrm{st}+14 \mathrm{a}$ for specimens from the rio Solimões of the Amazon basin, recently avoided with Pseudoplatystoma punctifer (Castelnau, 1855) by BuitragoSuarez \& Burr (2007). It also differs from the formulae found by Porto-Foresti et al. (2000) of $20 \mathrm{~m}+12 \mathrm{sm}+12 \mathrm{st}+12$ a for the same species in the rio Paraguay. Different karyotype formulae among populations of the same species from different hydrographic basins are usually evidence of karyotype evolution processes due to geographic isolation and an interruption in gene flow, as described in studies by MoreiraFilho et al. (1991) on Astyanax scabripinnis. NonRobertsonian events of the karyotypic diversification, the example of peri-and paracentric inversions are required to 


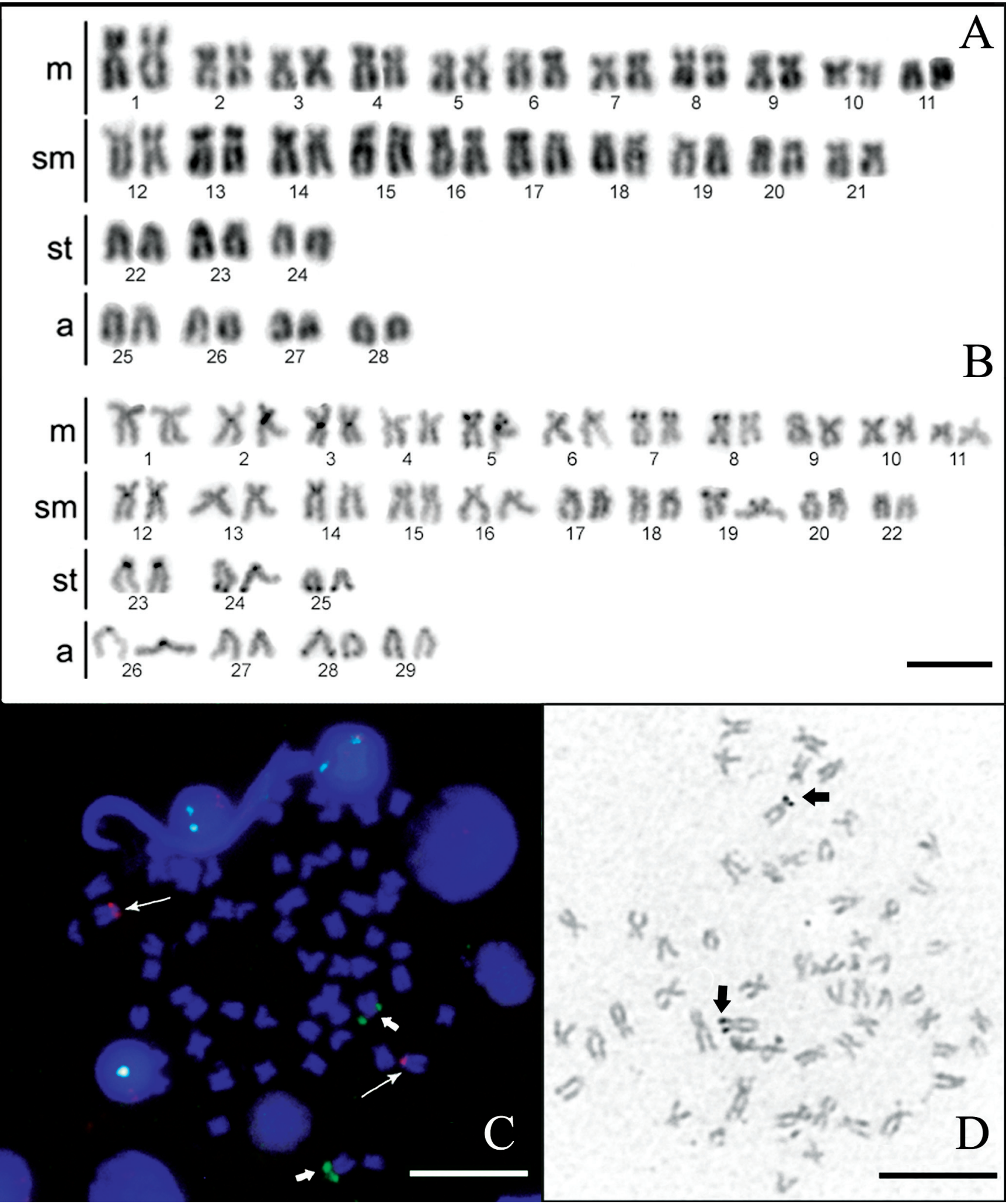

Fig. 1. Karyotype in Giemsa (A), C band (B), FISH with 18Sprobe (green arrows) and 5S probe (pink arrow) (C) and Ag-NORs (D) in Pseudoplatystoma reticulatum from the rio Paraguay (MS). $\mathrm{m}=$ metacentric; $\mathrm{sm}=$ submetacentric; $\mathrm{st}=$ subtelocentric; $\mathrm{a}=$ acrocentric. Scale bars $=10 \mu \mathrm{m}$.

explain the karyotypic differences observed among these populations of $P$. reticulatum. On the other hand, these chromosomes condensation, especially in these species that differences could be related to methodological problems or show smaller chromosomes than usual. However, this karyotype divergences among $P$. reticulatum population 


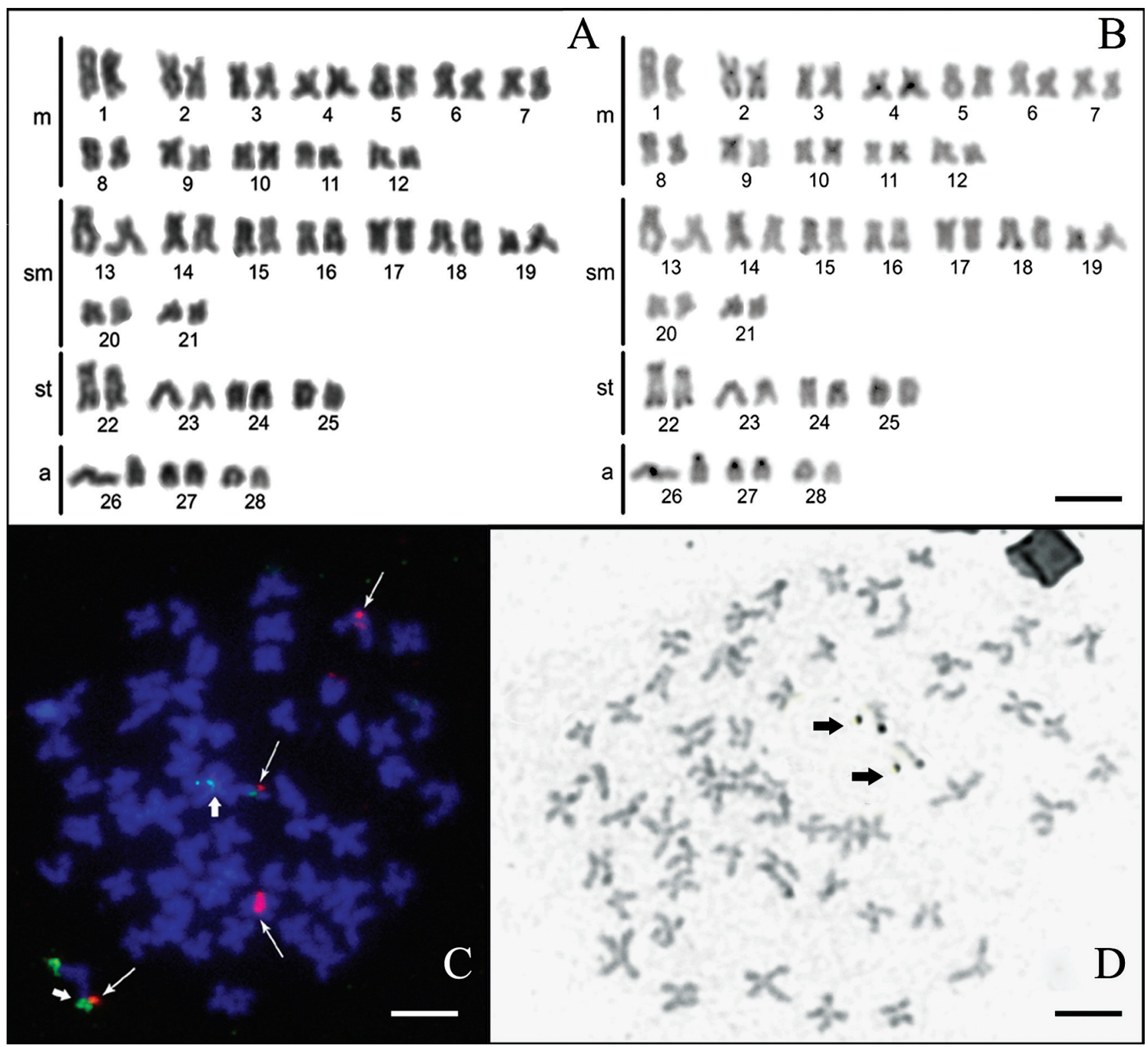

Fig. 2. Karyotype in Giemsa (A), C band (B), FISH with $18 \mathrm{~S}$ probe (green arrows) and $5 \mathrm{~S}$ probe (pink arrows) (C) and Ag-NORs (D) in Pimelodus britskii from the rio Iguaçu (PR). $\mathrm{m}=$ metacentric; $\mathrm{sm}=$ submetacentric; $\mathrm{st}=$ subtelocentric; a $=$ acrocentric. Scale bars $=10 \mu \mathrm{m}$.

could be reflecting their own biogeographical history with allopatric determination among rio Paraná, Paraguay, and São Francisco basins, similar the condition verified in Hypostomus genus, with isolament sugested about 5.7 to 6.4 m.a. (Montoya-Burgos, 2003).

The Steindachneridion parahybae case is especially important because it is the first karyotype description for the species, which is currently at high extinction risk and it is listed as threatened on the red list of the Brazilian Ministry of the Environment (Rosa \& Lima, 2008). The found macrostructure is not unlike that seen in others Pimelodidae, showing a high number of biarmed chromosomes, however, it has four pairs of acrocentric chromosomes. The chromosomal location of ribosomal cistrons evidenced by double FISH with $5 \mathrm{~S}$ probe in this specie, marked in the interstitial one pair of submetacentric chromosomes, whereas the $18 \mathrm{~S}$ probe was located on other chromosome pair. Swarça et al. (2005) studding the karyotype of Steindachneridion scriptum (cited as S. scripta), found a diploid number of 56 chromosomes with the karyotype $24 \mathrm{~m}+20$ $\mathrm{sm}+4 \mathrm{st}+8$ and $\mathrm{FN}=104$. The karyotype macrostructure does not differ from that described for other Pimelodidae species, with a high number of biarmed chromosomes, however, it shows four acrocentric chromosome pairs. The chromosomal location of the ribosomal cistrons was evidenced by the double-FISH method, with the $5 \mathrm{~S}$ probe tagged in the interstitial region in one pair of submetacentric chromosomes. The $18 \mathrm{~S}$ probe was located in one chromosome pair in telomeric regions of the short arms, although a polymorphism size became the marks in 


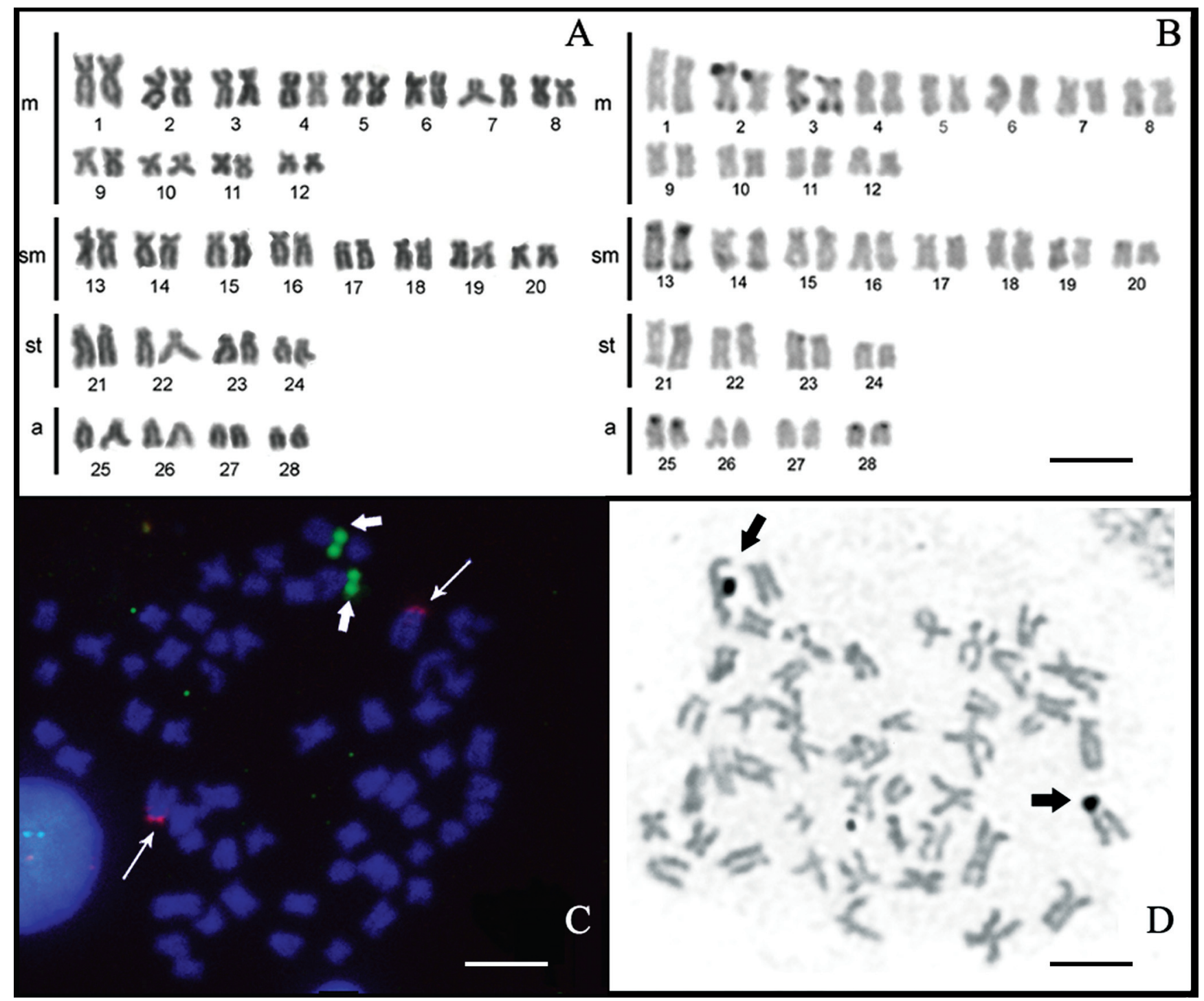

Fig. 3. Karyotype in Giemsa (A), C band (B), FISH with $18 \mathrm{~S}$ probe (green arrows) and $5 \mathrm{~S}$ probe (pink arrows) (C) and Ag-NORs (D) in Sorubim lima from the rio Paraguay (MS). $\mathrm{m}=$ metacentric; $\mathrm{sm}=$ submetacentric; $\mathrm{st}=$ subtelocentric; $\mathrm{a}=$ acrocentric . Scale bars $=10 \mu \mathrm{m}$.

one of the homologous chromosome almost imperceptible by FISH technique. This apparent lack of homology may be due to genic amplification in one of the homologous or chromosome breaks and deletions or even the chromosome segment of the other homologue having many small rDNA sites, which hampers their visualization.

The maintenance of $2 \mathrm{n}=56$ and $\mathrm{FN}=104$ as opposed to the karyotypic different formulae verified between $S$. scriptum and $S$. melanodermatum reinforces karyotype diversification through inversions event in these species, the example of what should occur on a larger scale among Pimelodidae. According Garavello (2005) six species of Steindachneridion genera are currently recognized along the coastal drainages of eastern and upper Paraná basin, Brazil. The S. parahybae is endemic fish of the rio Paraíba do Sul basin, while the $S$. scriptum has a wider distribution for the basins of the upper Paraná and rio Uruguay. However, the geographical isolation of these species regresses to 4.2 m.a. when comparatively analyzed the distribution of species of the genus Hypostomus between the upper Paraná and coastal basins (MontoyaBurgos, 2003). Similar to the one required to explain the karyotypic diversity among Pseudoplatystoma here also emphasize the importance of vicariance in the diversification of karyotypes of the Steindachneridion species.

Two karyotype descriptions were previously carried out for Sorubim lima by Fenocchio \& Bertollo (1992), who studied a population sample from the rio Solimões in the Amazon basin, and then by Martins-Santos et al. (1996), who analyzed a population from the rio Paraná in the upper Paraná basin. Although the studies were in agreement regarding the diploid number $(2 \mathrm{n}$ $=56$ chromosomes), the karyotype formulae were slightly different $(18 \mathrm{~m}+12 \mathrm{sm}+14 \mathrm{st}+12 \mathrm{a}$ and $20 \mathrm{~m}+14 \mathrm{sm}+10 \mathrm{st}+12 \mathrm{a}$, respectively), very likely for the reasons presented previously. The results of the present study on a population sample of S. lima from the rio 


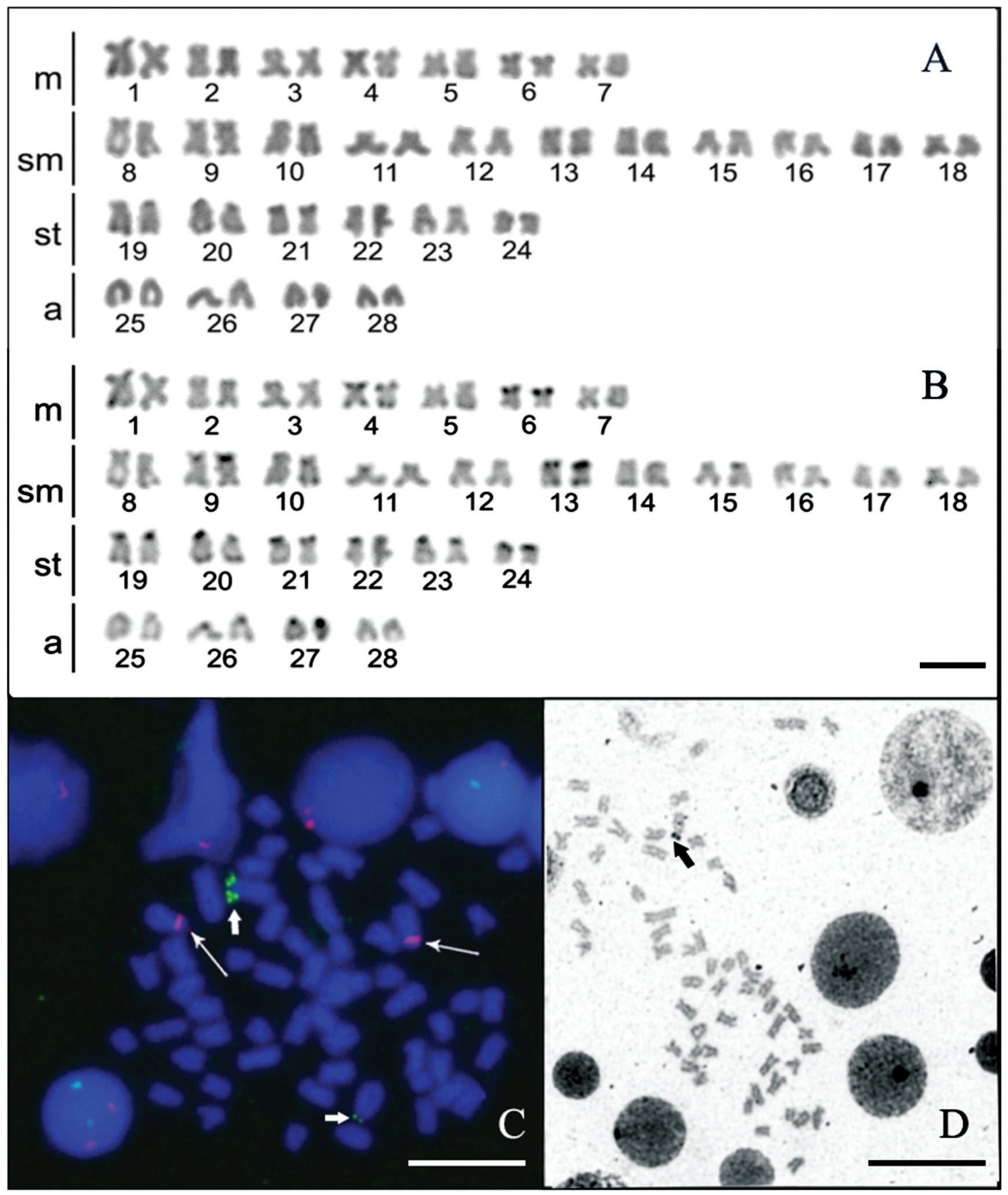

Fig. 4. Karyotype in Giemsa (A), C band (B), FISH with $18 \mathrm{~S}$ probe (green arrows) and $5 \mathrm{~S}$ probe (pink arrow) (C) and Ag-NORs (D) in Steindachneridion parahybae from the rio Paraíba do Sul (SP). $\mathrm{m}=$ metacentric; $\mathrm{sm}=$ submetacentric; st $=$ subtelocentric; $\mathrm{a}=$ acrocentric. Scale bars $=10 \mu \mathrm{m}$.

Paraguay corroborate the $2 n=56$ and diverge more expressively regarding the karyotype formulae $(24 m+16 s m+8 s t+8 a)$. These karyotypic discrepancies above pointed denote the presence of the chromosome rearrangements elapsed in geographical variations to exemplify what it was pointed out previously for $P$. reticulatum and S. parahybae. 
Heterochromatin markers have been employed by Fenocchio \& Bertollo (1992) in an attempt to distinguish the Pseudoplatystoma species. Our results indicate a large interspecific variation of heterochromatin distribution on the karyotypes of the species here analyzed. However, observed general features shows that the heterochromatic segments are located near the centromere and telomere of the chromosomes, and these bands are still evident. Some bitelomeric bands more consistent and markers can be evidenced in the Pseudoplatystoma reticulatum biarmed chromosomes (pair no. 8), Pimelodus britskii (pair no. 22), Sorubim lima (pair no. 13), and Steindachneridion parahybae (pair no. 8).

The collected karyotypic data practically distinguish the species and populations compared to other pimelodids already cytogenetically studied, although the modal diploid number of $2 \mathrm{n}=56$ chromosomes should be considered a feature shared by most species of this Neotropical fishes family.

The use of molecular cytogenetics, especially of fluorescent in situ hybridization (FISH) technique, particularly for the chromosomal location of rDNA probes, has appointed a very promising way for evolutionary analysis and cytotaxonomic in fish. In this case, we find a derived state for the distribution of $18 \mathrm{~S}$ ribosomal cistrons in synteny with regions $5 \mathrm{~S}$, the latter scattered in many others chromosomes in the Karyotype complement of Pimelodus britskii, an unusual condition among fish that may indicate an apomorphy for species, at least at the level of pimelodids already analyzed with these markers. The other species analyzed show single NOR on a single chromosome pair with chromosomal location and different types.

In conclusion, chromosome markers exploration related to karyotype formulae, chromosome banding and DNA probes location were significant not only for the cytogenetic characterization populations and species here showed, as well as to support the cytotaxonomy. The historical biogeography and the evolutionary time has also shown to be fundamental for the interpretation of the karyotypic differences verified among allopatric populations.

\section{Acknowledgements}

The authors are grateful to O. A. Shibatta (UEL) for species identified and Luiz A. M. Ludwig (COPEL - Usina Hidrelétrica Ney Braga), Danilo Caneppele (CESP - Usina Hidrelétrica de Paraibuna), Thiago T. Ushizima (MAR \& TERRA Ind. Com. Pescados Ltda) and João F. M. Sant'Anna for fish supply (BR-FISH Farm), for license to fishes captures. This study was supported by $\mathrm{CNPq}$ (Conselho Nacional de Desenvolvimento Científico e Tecnológico) and Fundação Araucária (Fundação Araucária de Apoio ao Desenvolvimento Científico e Tecnológico do Estado do Paraná). We also thank Miguel A. Carvalho for field and laboratory assistance.

\section{Literature Cited}

Artoni, R. F., M. R. Vicari, M. C. Almeida, O. Moreira-Filho \& L. A. C. Bertollo. 2009 Karyotype diversity and fish conservation of southern field from South Brazil. Review in Fish Biology and Fisheries, 19: 393-401.

Bertollo, L. A. C., C. S. Takahashi \& O. Moreira-Filho. 1978. Cytotaxonomic considerations on Hoplias lacerdae (Pisces, Erythrinidae). Brazilian Journal of Genetics, 1: 103-120.

Buitrago-Suarez, U. A. \& B. M. Burr. 2007. Taxonomy of the catfish genus Pseudoplatystoma Bleeker (Siluriformes: Pimelodidae) with recognition of eight species. Zootaxa, 1512: 1-38.

Caneppele, D., R. M. Honji, A. W. S. Hilsdorf \& R. G. Moreira. 2009. Induced spawning of the endangered Neotropical species Steindachneridion parahybae (Siluriformes: Pimelodidae). Neotropical Ichthyology, 7: 759-762.

Diniz, D., A. Laudicina \& L. A. C. Bertollo. 2009. Chromosomal location of 18S and 5S rDNA sites in Triportheus fish species (Characiformes, Characidae). Genetics and Molecular Biology, 32: 37-41.

Dover, G. A. 1986. Molecular drive in multigene families: how biological novelties arise, apread and are assimilated. Trends Genet, 2: 159-165.

Fenocchio, A. S. \& L. A. C. Bertollo. 1992. Karyotype similarities among Pimelodidae (Pisces, Siluriformes) from the Brazilian Amazon region. Cytobios, 69: 41-46.

Ferraris, Jr., C. J. 2007. Check list of catfishes, recent and fossil (Osteichthyes: Siluriformes) and catalogue of siluriform primary types. Zootaxa, 1418: 1-628.

Froese, R. \& D. Pauly. 2002. Fishbase. World Wide Web eletronic publication: www.fishbase.org, March 15, 2002.

Garavello, J. C. 2005. Revision of genus Steindachneridion (Siluriformes: Pimelodidae). Neotropical Ichthyology, 3: 607-623.

Garcia, C. \& O. Moreira-Filho. 2005. Cytogenetical analyses in three fish species of the genus Pimelodus (Siluriformes, Pimelodidae) from rio São Francisco: considerations about the karyotypical evolution in the genus. Neotropical Ichthyology, 3(2): 285-290.

Hatanaka, T. \& P. M. Galetti Jr. 2004. Mapping of the 18S and 5S ribosomal RNA genes in the fish Prochilodus argenteus Agassiz, 1829 (Characiformes, Prochilodontidae) Genetica, 3: 239-244.

Hilsdorf, A.W. \& M. Petrere Jr. 2002. Conservação de peixes na bacia do rio Paraíba do Sul. Ciência Hoje, 30: 62-67.

Howell, W. M. \& D. A. Black. 1980. Controlled silver-staining of nucleolus organizer regions with a protective colloidal developer: a 1-step method. Experientia, 36: 1014-1015.

Levan, A., K. Fredga \& A. A. Sandberg. 1964. Nomenclature for centromeric position on chromosomes. Hereditas, 52: 201-220.

Ludwig, L. A. M., E. Gomes \& R. F. Artoni. 2005. A method of induced reproduction for surubim Steindachneridion melanodermatum (Siluriformes, Pimelodidae) of the rio Iguaçu. Publicatio UEPG: Biological and Health Sciences, 11(3/4): 23-27.

Lundberg, J. G. \& M. W. Littmann. 2003. Family Pimelodidae. Pp. 432-442. In: Reis, R. E., S. O. Kullander \& C. J. Ferraris Jr. (Eds.). Check list of the freshwater fishes of South and Central America. Porto Alegre, Edipucrs, 729p.

Martins, C. \& P. M. Galetti Jr. 1999. Chromosomal location of 5S rDNA genes in Leporinus fish (Anostomidae, Characiformes). Chromosome Research, 7: 363-367.

Martins, C. \& P. M. Galetti Jr. 2000. Conservative distribution of $5 \mathrm{~S}$ rDNA loci in Schizodon (Pisces, Anostomidae) chromosomes. Chromosome Research, 8: 353-355. 
Martins, C. \& P. M. Galetti Jr. 2001. Organization of 5S rDNA in species of the fish Leporinus: Two different genomic locations are characterized by distinct nontranscribed spacers. Genome, 44: 903-910.

Martins-Santos, I. C., H. F. Julio Jr \& I. Burin. 1996. Karyotypic studies of four species of the Sorubiminae subfamily (Pisces, Siluriformes). Caryologia, 49: 73-80.

Miranda, M. O. T. 1997. Surubim. Belo Horizonte, IBAMA, Coleção Meio Ambiente, Série Estudos Pesca, 19p.

Montoya-Burgos, J. I. 2003. Historical biogeography of the catfish genus Hypostomus (Siluriformes: Loricariidae), with implications on the diversification of Neotropical ichthyofauna. Molecular Ecology, 12: 1855-1867.

Moreira-Filho, O. \& L. A. C. Bertollo. 1991. Astyanax scabripinnis (Pisces, Characidae): a species complex. Brazilian Journal of Genetics, 14: 331-357.

Oliveira, C., L. F. Almeida-Toledo \& F. Foresti. 2005. Karyotypic evolution in Neotropical fishes. Pp. 1-49. In: Pisano, E., C. Ozouf-Cotaz, F. Foresti \& B. G. Kapoor. (Orgs.). Fish Cytogenetics. 1 Ed. Enfield: Science Publisher Inc.

Pinkel, D., T. Straume \& J. W. Gray. 1986. Cytogenetic analysis using quantitative, high-sensitivity, fluorescence hybridization. Proceedings of National Academic Science USA, 83: 2934-2938.

Oliveira, C. \& A. E. Gosztonyi. 2000. A cytogenetic study of Diplomystes mesembrinus (Teleostei, Siluriformes, Diplomystidae) with a discussion of chromosome evolution in siluriforms. Caryologia, 53: 31-37.

Porto-Foresti, F., A. A. Andreata, C. Oliveira \& F. Foresti. 2000. The Karyotype of Pseudoplatystoma fasciatum (Teleostei, Siluriformes) from the Rio Paraguay basin. Chromosome Science, 4: 99-102.

de Pinna, M. C. C. 1998. Phylogenetic relationships of Neotropical Siluriformes (Teleostei, Ostariophysi): historical overview and synthesis of hypotesis. Pp. 279-330. In: Malabarba, L. R., R. E. Reis, R. P. Vari, Z. M. S. Lucena \& C. A. S. Lucena (Eds.) Phylogeny and classification of Neotropical fishes. Porto Alegre, Edipucrs, 603p.

Revaldaves, E., L. H. G. Pereira, F. Foresti \& C. Oliveira. 2005. Isolation and characterization of microsatellite loci in Pseudoplatystoma corruscans (Siluriformes: Pimelodidae) and cross-species amplification. Molecular Ecology Notes, 5: 463-465.

Ribeiro, F. R. \& C. A. S. Lucena. 2006a. Nova espécie de Pimelodus (Siluriformes, Pimelodidae) dos rios Tapajós e Tocantins, Brasil. Iherigia, Série Zoologia, 96(3): 321-327.

Ribeiro, F. R. \& C. A. S. Lucena. 2006b. Anew species of Pimelodus La Cépède, 1803 (Siluriformes: Pimelodidae) from the rio São Francisco drainage, Brazil. Neotropical Ichthyology, 4(4): 411-418.

Rosa, S. R. \& F. C. T. Lima. 2008. Os peixes brasileiros ameaçados de extinção. In: Livro vermelho da fauna brasileira ameaçada de extinção. Machado, A. B., G. M. Drumond \& A. P. Paglia (Orgs.). Brasília, DF. Ministério do Meio Ambiente, 275p.

Sumner, A. T. 1972. A simple technique for demonstrating centromeric heterochromatin. Experimental Cell Research, 75: 304-306.

Swarça, A. C., M. M. Cestari, L. Giuliano-Caetano \& A. L. Dias. 2001. Cytogenetic characterization of the large South American siluriform fish species Zungaro zungaro (Pisces, Pimelodidae). Chromosome Science, 5: 51-55.

Swarça, A. C., A. S. Fenocchio, M. M. Cestari \& A. L. Dias. 2005. Karyotype divergence among populations of giant catfish Pseudoplatystoma corruscans (Teleostei: Pimelodidae) indicates higher species diversity. Ichthyological Exploration of Freshwaters, 16: 325-330.
Swarça, A. C., A. S. Fenocchio \& A. L. Dias. 2007. An update cytogenetic review for species of the families Pseudopimelodidae, Pimelodidae and Heptapteridae (Pisces, Siluriformes). Suggestion of a cytotaxonomical classification. Caryologia, 60: 338-348.

Accepted October 6, 2010

Published March 31, 2011 